\title{
KARAKTER SPASIAL ARSITEKTUR DALEM KABUPATEN DI KOTA-KOTA PESISIR UTARA JAWA
}

\author{
Deny Setya Afriyanto \\ Mahasiswa Program Studi Magister Arsitektur, Departemen Arsitektur dan Perencanaan, \\ Universitas Gadjah Mada \\ e-mail: deny.setya.afriyanto@mail.ugm.ac.id \\ Dyah Titisari Widyastuti \\ Dosen Program Studi Magister Arsitektur, Departemen Arsitektur dan Perencanaan, \\ Universitas Gadjah Mada \\ e-mail: dyahtitisariw@ugm.ac.id
}

\begin{abstract}
ABSTRAK
Bentuk pusat kota tradisional Jawa dibentuk dari serangkaian elemen yang utamanya terdiri dari alun-alun, masjid, dan istana/tempat tinggal pemimpin. Ruang pusat kota tradisional di pesisir utara Jawa merupakan miniatur keraton. Pada pusat kota pesisir utara Jawa, tidak terdapat istana kerajaan melainkan bangunan tempat tinggal pemimpin yang disebut sebagai Dalem Kabupaten. Sebagai bagian dari pusat kota tradisional Jawa, karakter spasial Dalem Kabupaten perlu untuk diketahui sebagai bagian dari perkembangan sejarah kawasan kota bersejarah. Dalam rangka mengetahui karakter spasial dari Dalem Kabupaten, penelitian ini menggunakan metode kualitatif, sementara pengumpulan data melalui data literatur dan observasi. Kegiatan observasi di sini dilakukan untuk mengetahui kondisi lapangan mengenai aspek-aspek yang berhubungan dengan keruangan arsitektur Dalem Kabupaten seperti setting, orientasi, tata massa, dan denah bangunan. Berdasarkan hasil penelitian ini diketahui bahwa terdapat pola dominan dalam arah orientasi bangunan Dalem Kabupaten yaitu menghadap ke utara, sementara Jepara merupakan satusatunya Dalem Kabupaten yang menghadap ke arah barat. Dalam skala denah dan tata massa bangunan Dalem Kabupaten memiliki komponen inti berupa pendopo, pringgitan, dalem, dan gandok. Diketahui pula bahwa bangunan dalem pada Dalem Kabupaten tidak memiliki senthong tengah. Hal ini merupakan pengaruh dari karakter kota pesisir dan berbeda dengan karakter kota pedalaman.
\end{abstract}

Kata kunci : Dalem Kabupaten, Karakter, Kota Pesisir

\section{ABSTRACT}

The traditional city center on the north coastal city of Java emulates the concept of royal palace that consist of mainly elements such as the square, mosque, and palace/residence of the regent. As part of the traditional Javanese city center, the spatial character of Dalem Kabupaten needs to be recognized as part of the historical development of the historic city area. In order to know the spatial character of Dalem Kabupaten, the of this research 
was qualitative, while data collecting is conducted through literature and observation data. Observation carried out to determine the field conditions regarding aspects related to the architectural spatial of Dalem Kabupaten. Based on the results of this study, it is known that there is a dominant pattern in the orientation of the Dalem Kabupaten which facing north, except for Jepara which facing west. Dalem Kabupaten has a core component in the form of a pendapa, pringgitan, dalem, and gandok. It is also known that the dalem building in the Dalem Kabupaten does not have a central room (senthong tengah). This is an influence of the character of a coastal city that different from the character of an inland city.

\section{Keywords : Coastal City, Dalem Kabupaten, Spatial Character}

\section{PENDAHULUAN}

Suatu objek arsitektur dapat dikatakan memiliki karakter tertentu apabila memiliki ciri khusus yang membedakannya dengan objek arsitektur lainnya. Karakter dalam arsitektur dapat didefinisikan sebagai sesuatu yang melekat pada suatu objek dan dapat berupa aspek fisik maupun non fisik. Hal ini karena suatu arsitektur juga berkaitan dengan pengaruh faktor alam sehingga antara lokasi satu dengan yang lainnya memiliki karakter yang berbeda (Hastati, 2003). Karakter arsitektur dapat diwujudkan dalam skala bangunan maupun skala kota, pun demikian segala aspek yang terlibat di dalamnya termasuk ruang.

Ruang kota dibentuk dari serangkaian elemen di antaranya jalan, bidang tanah, bangunan-bangunan, bentukan alam, serta aspek kehidupan sosial dan budaya penghuninya yang berkembang seiring berjalannya waktu. Kota seringkali dianggap sebagai wilayah yang lebih padat penduduk dan lebih heterogen jika dibandingkan dengan wilayah pedesaan. Oleh karena itu infrastruktur dan fasilitas kota biasanya lebih lengkap jika dibandingkan dengan pedesaan (Basundoro, 2020: 4). Sebagai suatu satuan ruang geografis, kota memiliki apa yang disebut sebagai 'pusat kota' yang dalam istilah asing dikenal pula sebagai urban center atau urban core. Dengan berbagai fasilitas yang ada di wilayah pusat kota ini maka ada pula yang menyebutnya sebagai civic center atau pusat pemerintahan (Damayanti dan Handinoto, 2005: 34). Area pusat pemerintahan ini juga ada pada kota-kota di Jawa yang sudah memiliki pola tertentu sejak masa pra Islam.

Pembentukkan kota di Jawa mengikuti struktur kota pada masa pra Islam. Konsep kota-kota ini didasarkan pada makrokosmos dan mikrokosmos dimana terdapat mandala sebagai pusat kota yang berupa istana penguasan dengan alun-alun dan bangunan penting lainnya sebagai simbol kekuasaan fisik yang dimiliki oleh penguasa setempat. Adanya alun-alun, masjid, dan istana/tempat tinggal pemimpin tidak hanya dapat dilihat pada struktur pusat

PAWON: Jurnal Arsitektur, Nomor 02 Volume V, Juli-Desember Tahun 2021, ISSN 2597-7636 
kota kerajaan seperti Kasunanan Surakarta dan Keraton Yogyakarta melainkan juga pada struktur kota baik di pedalaman maupun pesisir. Kedua jenis kota ini, baik pedalaman maupun pesisir dibedakan berdasarkan kondisi geografis-kultural yang lebih ditekankan pada kota sakral yang agraris, dan geografis ekonomis yang lebih ditekankan pada kota perdagangan (Handinoto, 2015: 1). Secara administratif wilayah mancanegara ini disebut sebagai wilayah kabupaten yang dipimpin oleh seorang bupati. Pada saat pemerintahan Mataram Islam, gelar pemimpin dapat berupa bupati atau syahbandar yang biasanya diberi pangkat tumenggung, kiai demang, atau kiai ngabehi. Para bupati atau syahbandar di wilayah pesisir ini memiliki kekuasaan penuh untuk memerintah daerah yang menjadi wewenangnya meskipun tidak terlepas dari pengawasan pejabat tinggi kerajaan di Kutaraja (Anonim, 2017: 49).

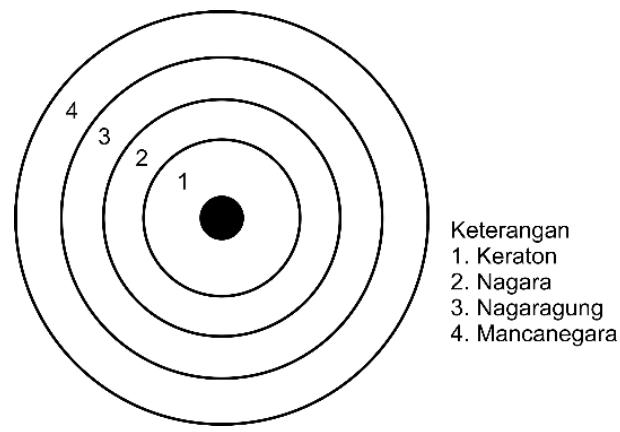

Gambar. 1

Susunan tata pemerintahan Keraton Yogyakarta Sumber: Selo Soemardjan, (1991)

.Kota pesisir Jawa merujuk pada satuan wilayah yang berada di garis pantai, baik di sisi selatan maupun utara. Secara geografis, pesisir utara Jawa Tengah merupakan wilayah yang membentang di sepanjang Pantai Utara Jawa dari Brebes di bagian barat hingga Rembang di bagian timur. Hingga abad ke XVI wilayah-wilayah pesisir ini merupakan wilayah otonom yang berjalan sendiri-sendiri baik dari aspek ekonomi maupun pemerintahannya. Kemudian, sejak abad XVII, pada masa Sultan Agung wilayah-wilayah ini disatukan menjadi satu kekuasaan Mataram dan dikenal dengan nama daerah "Pesisir" (Hartatik, 2018: 43). Sebutan kota pesisir juga berasal dari dari orang pedalaman yang mengacu pada wilayah di luar daerah pedalaman tersebut. Pesisir merujuk pada wilayah pantai mulai dari Cirebon di sebelah barat hingga Surabaya di sebelah timur (Lombard, 2018). Adanya wilayah pesisir ini didasari pula pada pembagian struktur kota masa Mataram Islam di bawah kepemimpinan Sultan Agung. Pada masa kemudian, istilah pesisir Jawa juga digunakan untuk merujuk pada satuan wilayah yang berada di garis pantai, baik di sisi selatan maupun utara sehingga apa yang dimaksud 
sebagai kota pesisir di masa pemerintahan Mataram Islam kini dikenal sebagai wilayah pesisir utara Jawa.

Ruang pusat kota tradsional Jawa di pesisir utara Jawa selama ini dianggap memiliki sumbu orientasi utara-selatan layaknya kota kerajaan di wilayah pedalaman. Namun demikian pada kota pesisir utara Jawa juga terdapat kota yang memiliki orientasi ke arah barat timur seperti pada Dalem Kabupaten Jepara. Sementara kota-kota lain dalam kajian ini yaitu Brebes, Pekalongan, dan Rembang memiliki sumbu orientasi utara selatan yang mengikuti pola umum. Sumbu orientasi kota ini berpengaruh pada setting/perletakan elemen-elemen pusat kota, salah satu elemen pusat kota tersebut adalah Dalem Kabupaten.Karakter yang berhubungan dengan aspek spasial arsitektur ini kiranya perlu didalami untuk mencari hubungan antara keberadaan Dalem Kabupaten dengan lingkungan sekitar yang saling mempengaruhi.

Dalem Kabupaten yang merupakan salah satu bangunan di dalam area pusat kota di pesisir yang dipakai sebagai simbol kekuasaan atau 'istana' pemimpin setempat. Bupati pada jaman dulu juga memiliki para abdi yang tinggal di dalam kompleks Dalem Kabupaten. Oleh karena itu Sukesi (1985:11) berpendapat bahwa hingga permulaan abad 20 dapat dipastikan bahwa keluarga yang tinggal di dalam Dalem Kabupaten selalu berjumlah besar. Sebagai gambaran, kedudukan Dalem Kabupaten ini mencontoh keberadaan Kraton Yogyakarta dan Surakarta, namun dalam skala kabupaten, besaran keluarga yang tinggal di Dalem Kabupaten tidak dapat dibandingkan dengan istana kerajaan seperti Kraton Yogyakarta dan Surakarta yang jauh lebih besar dan kompleks.

Saat ini, tidak semua Dalem Kabupaten dimanfaatkan sebagai pusat administratif ataupun tempat tinggal bupati. Kasus-kasus di Jawa Tengah menunjukkan keragaman fungsi ini seperti ditunjukkan pada Kabupaten Rembang dan Kabupaten Pekalongan. Dalem Kabupaten Rembang saat ini dipergunakan sebagai Museum R.A. Kartini sedangkan Dalem Kabupaten Pekalongan, yang karena terdapat perubahan administratif wilayah (kini berada di Kota Pekalongan), tidak lagi difungsikan sebagai tempat tinggal bupati dan dapat disewa oleh masyarakat umum untuk menggelar hajatan. Lain halnya dengan kasus pada Dalem Kabupaten Jepara dan Brebes yang masih menjadi tempat tinggal bupati namun tidak berfungsi sebagai lokasi kantor bupati.

Dalem Kabupaten merupakan bagian dari suatu pusat kota tradisional Jawa yang dalam setting yang lebih luas juga bagian dari lanskap kota bersejarah. Sebagai bagian dari lanskap kota bersejarah, Dalem Kabupaten perlu dilihat karakter arsitekturnya sehingga dapat dijadikan acuan pelestarian di masa mendatang. Dengan mengetahui karakternya, pelestarian dapat berkesinambungan dengan keberlanjutan perencanaan, dan intervensi

PAWON: Jurnal Arsitektur, Nomor 02 Volume V, Juli-Desember Tahun 2021, ISSN 2597-7636 
desain dengan memperhatikan lingkungan binaan yang ada, dinamika sosial, sejarah, dan budaya yang melekat di dalamnya. Selain itu penelitian mengenai karakter spasial ini digunakan untuk melihat relasi ruang baik di dalam area pusat kota Jawa, kompleks Dalem Kabupaten, dan susunan ruang bangunan Dalem Kabupaten dengan konteks kota pesisir.

\section{TINJAUAN PUSTAKA}

Dalam ranah arsitektur, karakter merupakan sesuatu yang melekat pada objek arsitektur yang dapat berupa aspek fisik maupun non fisik. Hal ini karena suatu arsitektur juga berkaitan dengan pengaruh faktor alam sehingga antara lokasi satu dengan yang lainnya memiliki karakter yang berbeda. Sementara itu, karakter spasial dapat dipandang sebagai salah satu aspek untuk melihat kaitan antara organisasi ruang mencakup hubungan ruang, orientasi, dan sebagainya. Oleh karena itu penggambaran Dalem Kabupaten juga perlu dilihat dari hubungan-hubungan ini untuk mengetahui karakternya ditinjau dari aspek spasial.

Seorang bupati menempati suatu kediaman yang berada di suatu pusat kota dengan komponen kota seperti keberadaan alun-alun dan masjid yang mirip dengan kota kerajaan. Jika di kota kerajaan tempat tinggal raja dapat disebut sebagai keraton sedangkan pada rumah kediaman bupati disebut sebagai Dalem Kabupaten. Dalem Kabupaten merujuk pada kompleks bangunan seperti halnya penyebutan Dalem Pangeran yang merujuk pada rumah pangeran di wilayah kasultanan. Oleh karena itu penyebutan dalem di sini dimaksudkan untuk melihat perspektif keseluruhan komponen bangunan yang ada di dalam kompleks.
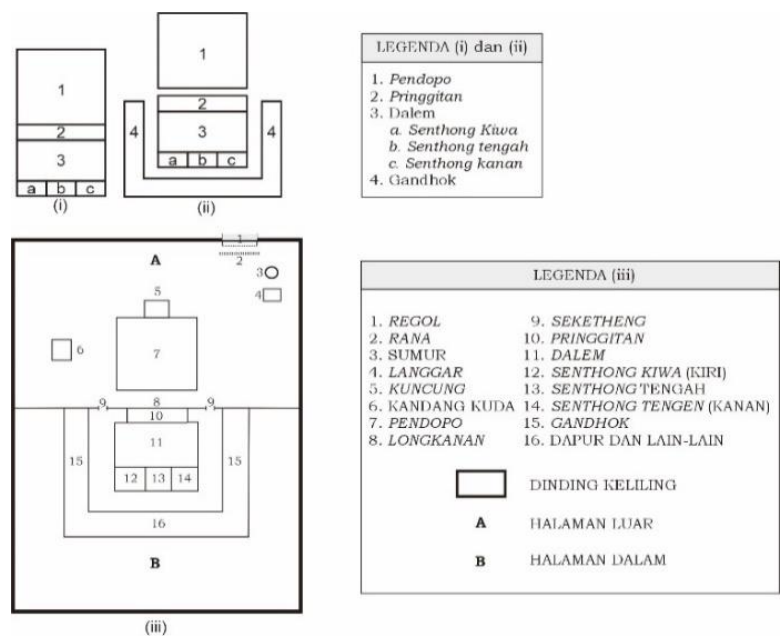

PAWON: Jurnal Arsitektur, Nomor 02 Volume V, Juli-Desember Tahun 2021, ISSN 2597-7636 
Gambar. 2

Skema kompleks rumah Joglo: (i) rumah orang biasa; (ii) rumah bangsawan; dan (iii) yang paling lengkap

Sumber: H. J. Wibowo dkk, (1986: 61-65)

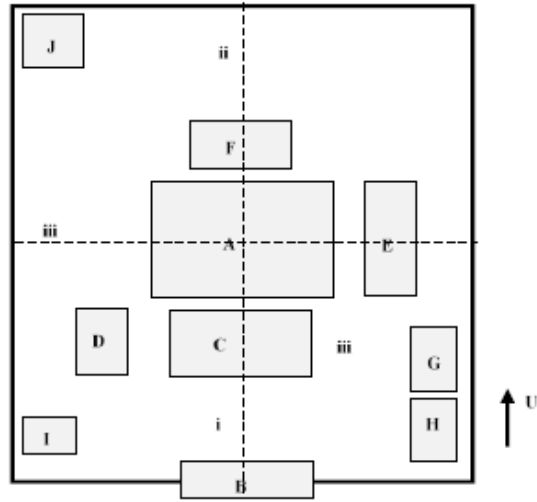

Legenda :

$\mathrm{A}=$ omah $; \mathrm{B}=$ regol; $\mathrm{C}=$ pendopo $; \mathrm{D}=$ pagongan

$\mathrm{E}=\mathrm{Gandok} ; \mathrm{F}=\mathrm{Paw}$; $; \mathrm{G}=\mathrm{Kandang}$ rajakaya

$\mathrm{H}=$ Gedhokan jaran; $\mathrm{I}=$ Langgar;

$\mathrm{J}=$ Sanggar pamujan; $\mathrm{i}=$ latar; $\mathrm{ii}=\mathrm{kebun} ; \mathrm{iii}=$ godagan

Gambar. 3

Denah tata masa bangunan di dalam rumah tradisional Jawa menurut Primbon Jawa Pandita Sabda Nata (1976)

Sumber: Gatot Adi Susilo, (2018:62)

Dalam rumah-rumah masyarakat Jawa, komponen bangunan yang dimiliki cukup beragam. Skema kelengkapan kompleks joglo dapat digunakan untuk mendefinisikan rumah bangsawan dan masyarakat biasa $(H$. J. Wibowo, dkk, 1986: 61-65). Versi lain dari kelengkapan rumah tradisional Jawa dapat disadur dari naskah "Primbon Djawa Pandita Sabda Nata" (himpunan R.Tanaja) yang dikutip oleh Prijotomo (1999). Dalam naskah tersebut kelengkapan bangunan tradisional Jawa meliputi omah, regol, pendopo, pagongan, gandok, pawon, kandang rajakaya, gedhokan jaran, langgar, sanggar pamujan, latar, kebun, dan godhagan (Prijotomo, 1999: 33; Susilo, 2018: 62).

Mengenai komponen bangunannya, Sukesi (1985) menyatakan bahwa Dalem Kabupaten terdiri dari empat komponen utama yaitu pendopo, pringgitan, dalem, dan gandok. Sementara itu disebutkan pula bahwa pada bagian Dalem agak sedikit berbeda dengan susunan ruang yang selama ini melekat pada bangunan rumah tradisional Jawa dimana pada Dalem Kabupaten pasisiran ini tidak ditemukan adanya senthong kiwa, senthong tengen, maupun senthong tengah. Secara umum diterangkan pula bahwa Dalem Kabupaten di pesisir memiliki susunan ruang yang terdiri dari ruang tengah yang disebut jerambah dan berfungsi sebagai ruang keluarga. 
Ruangan tersebut diapit oleh masing-masing dua baris kamar yang menjadi ruang kamar tidur keluarga. Pada bagian belakang terdapat ruang serambi atau yang disebut pendapa belakang, bagian ini biasanya digunakan sebagai ruang keluarga untuk para wanita. Pada bagian kanan-kiri bangunan terdapat bangunan yang disebut sebagai gandok (paviliun). Satu gandok ini biasanya digunakan untuk tempat tinggal keluarga yang sudah sepuh, sementara yang lain dipergunakan sebagai kamar-kamar bagi para pendherek (abdi).

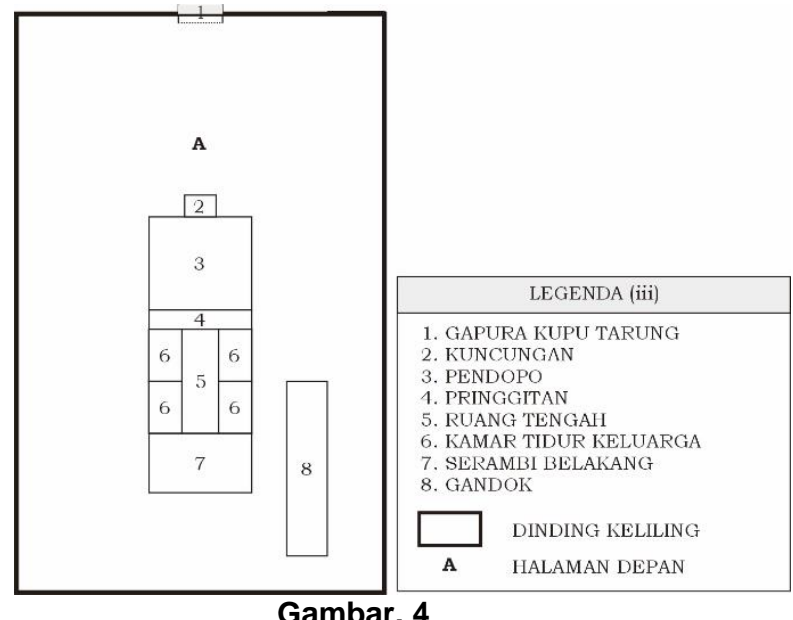

Denah Dalem Kabupaten Pasisiran

Sumber: Ilustrasi dari narasi deskripsi Sukesi, 1985)

Dalem Kabupaten memiliki struktur pusat kota yang dianggap sebagai miniatur model keraton. Meskipun wilayah pesisir di dalam berbagai sumber disebutkan bahwa arsitekturnya banyak mengalami pengaruh dari luar, namun struktur pusat kotanya masih memiliki pola yang sama dengan kota kerajaan. Hal ini dapat dilihat dari keberadaan Dalem Kabupaten, alun-alun, dan masjid. Ketiga elemen tersebut merupakan unsur pokok yang dimiliki Dalem Kabupaten (Sukesi, 1985).

Selain orientasi terhadap arah mata angin yang mencerminkan keberadaan dewa-dewa di setiap penjurunya (Trisusilowati, 2013; Musman (2017: 53), masyarakat Jawa juga memiliki pedoman lain dalam menghadapkan bangunan rumah. Arah orientasi ini menggunakan himpunan air (bandaran agung) di bagian depan sedangkan di bagian belakangnya membelakangi dataran tinggi, bukit atau gunung. Penggunaan arah orientasi ini tidak didapatkan pada ajaran Hindu India seperti yang tertera pada kitab Vastusastra. Pada kitab Vastusastra orientasi yang digunakan adalah arah terbitnya matahari saja (Ambarwati, 2009). Bangunan tradisional Jawa umumnya memiliki orientasi ke utara-selatan sebagaimana wilayah Jawa yang bagian tengahnya berupa area pegunungan. Wibowo dan Muafani (2015) membandingkan arah orientasi Pendopo Kabupaten yang dalam 
kesimpulannya menyebutkan bahwa Pendopo Kabupaten memiliki arah orientasi ke laut, baik keberadaan Laut Jawa di sisi utara maupun Samudra Indonesia di sisi selatan.

\section{METODE PENELITIAN}

Penelitian ini menggunakan metode kualitatif. Hal ini didasarkan pada alur penelitian yang bergerak dari kajian fakta-fakta atau gejala-gejala khusus untuk mencari hubungan-hubungan tertentu dalam suatu variabel permasalahan. Proses pengambilan data dalam penelitian ini dilakukan melalui observasi lapangan dan studi literatur.

Melalui observasi, gambaran mengenai setting dan orientasi kota tradisional Jawa, komposisi tata massa bangunan, serta denah ruang dapat diperoleh. Sementara itu data literatur akan membantu mengkonstruksi data mengenai pusat kota tradisional Jawa dan bangunan tradisional Jawa Kedua data ini kemudian disintesakan untuk menjawab permasalahan penelitian. Permasalahan penelitian yang dibahas adalah mengenai karakter spasial arsitektur Dalem Kabupaten. Karakter spasial dapat diamati melalui setting, orientasi, tata massa, dan susunan ruang. Adapun penelitian ini dibatasi pada empat Dalem Kabupaten yaitu Kabupaten Rembang, Kabupaten Jepara, Kabupaten Brebes, dan Kota Pekalongan.

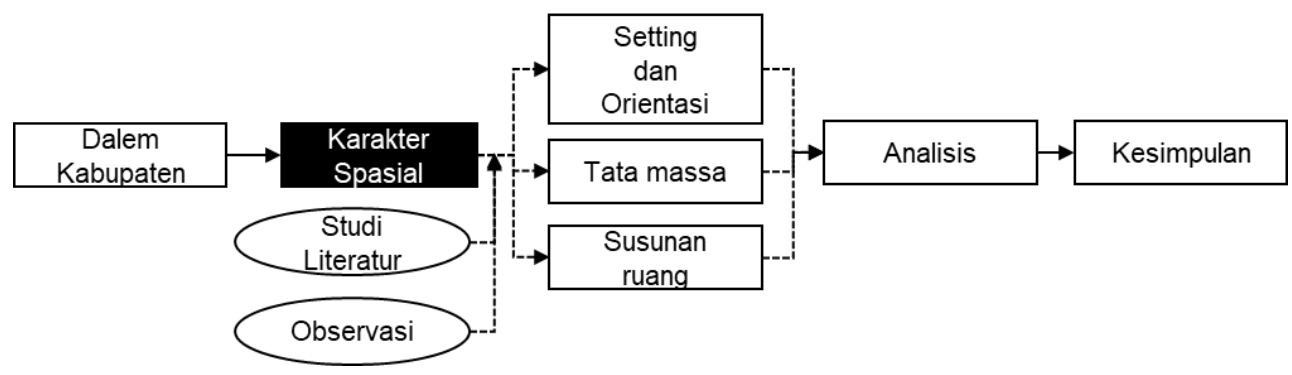

Gambar. 5

Bagan alir penelitian

\section{HASIL DAN PEMBAHASAN}

\subsection{Setting dan Orientasi}

Setting dan orientasi Dalem Kabupaten sebagai elemen inti kota Jawa dapat dilihat melalui keberadaan komponen fisiknya yang disandingkan dengan infrastruktur dan elemen alam. Baik Dalem Kabupaten, masjid, alunalun merupakan elemen inti yang menjadi pusat pemerintahan di dalam kota tradisional Jawa. Elemen ini juga dimiliki kota-kota pesisir seperti Brebes, Pekalongan, Jepara, dan Rembang. 


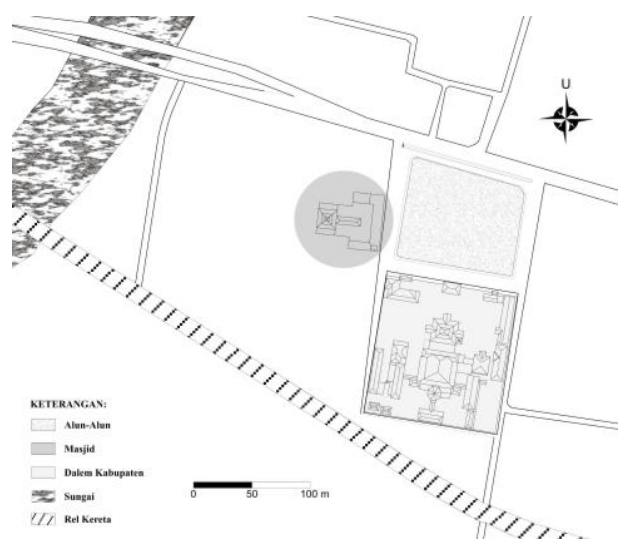

(a)

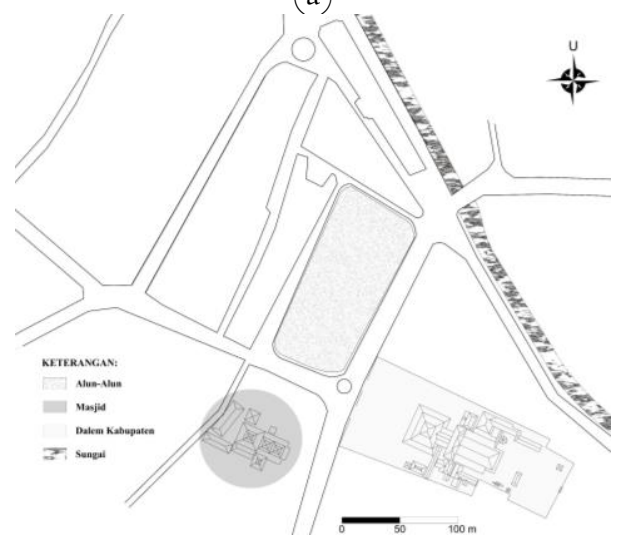

(c)

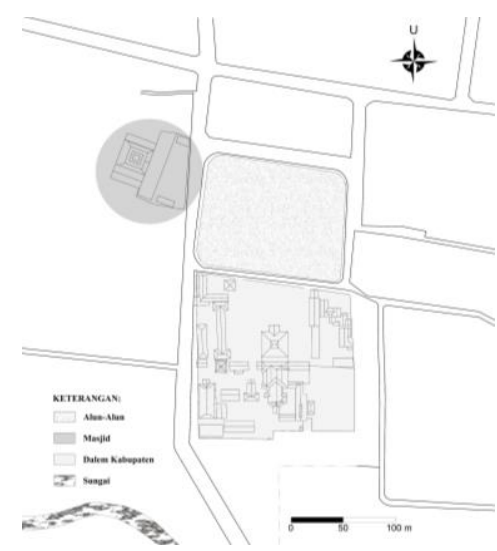

(b)

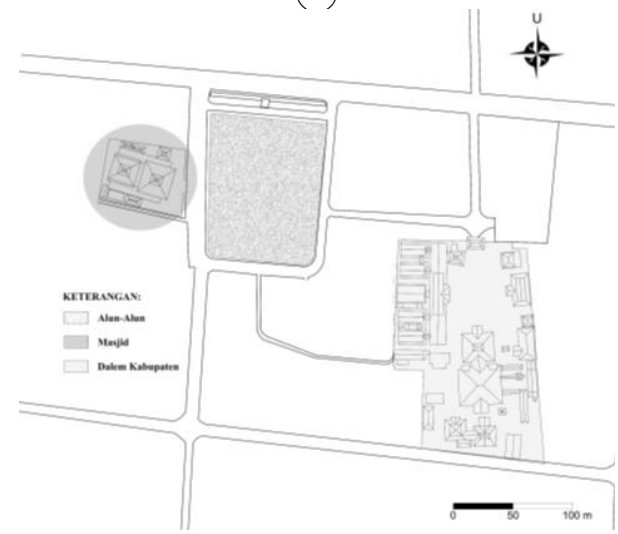

(d)

Gambar. 6

Setting pusat kota tradisional Jawa pada lokasi penelitian (a) Brebes; (b) Pekalongan; (c) Jepara; dan (d) Rembang

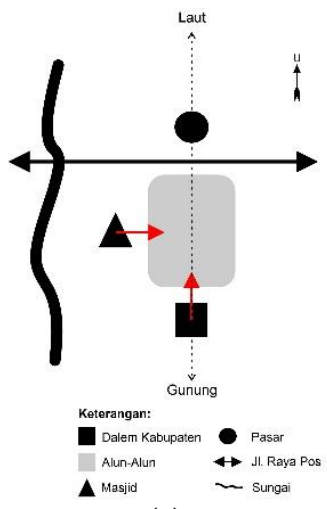

(a)

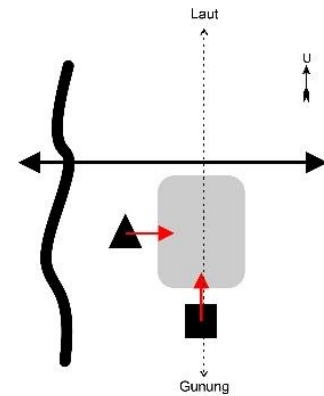

Keterangan:

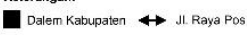

Alun-Alun Sungal

Mas

(b)

PAWON: Jurnal Arsitektur, Nomor 02 Volume V, Juli-Desember Tahun 2021, ISSN 2597-7636 


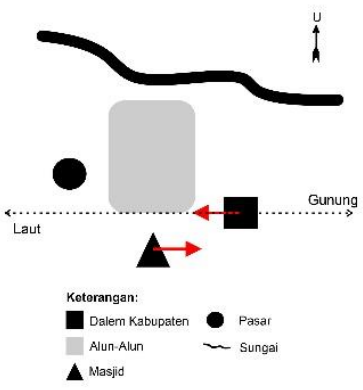

(c)

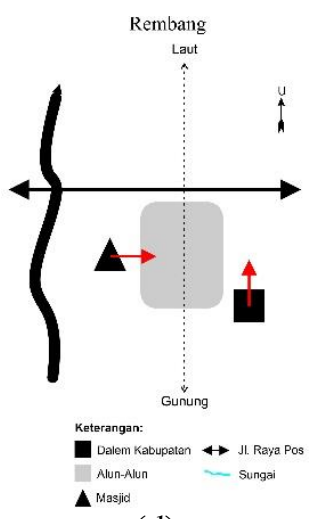

(d)

Gambar. 7

Skematik setting kota dan orientasi Dalem Kabupaten: (a) Brebes; (b) Pekalongan; (c) Jepara; dan (d) Rembang

Di antara keempat setting pusat kota di atas, Jepara memiliki satu setting pusat kota yang paling berbeda jika dibandingkan dengan kota lainnya. Perbedaaan ini dapat dilihat dari beberapa hal yaitu pusat Kota Jepara tidak dilalui jalan raya Pos seperti halnya ketiga kota lainnya, posisi arus sungai utama yang biasanya membujur dari arah selatan menuju utara pada pusat kota Jepara justru melintang dari timur menuju laut di arah barat yang juga merupakan posisi di mana Pelabuhan berada. Jika dilihat dari aspek ekonomi, pelabuhan merupakan pusat vital yang mana di lokasi tersebut terdapat aktivitas bongkar muat. Keberadaan pasar yang juga berada di dekat sungai ini merupakan jalur distribusi perniagaan ke sisi kota lainnya (Lombard, 2018: 272). Keberadaan pasar yang mendekati sungai ini juga ditemui pada Dalem Kabupaten Brebes, yang berada di sisi utara alun-alun. Juga, telah disinggung bahwa bangunan tradisional Jawa juga memiliki orientasi menghadap himpunan air dan membelakangi bukit, gunung, atau dataran tinggi. Secara geografis, pulau Jawa memiliki dataran tinggi dan gunung di bagian tengah sehingga pada Dalem Kabupaten baik di Brebes, Pekalongan, dan Rembang memiliki arah orientasi yang sama yakni ke arah utara. Dalam hal ini Jepara, yang merupakan wilayah paling utara justru memiliki arah orientasi ke barat. Jika merujuk pada pemahaman bahwa bangunan tradisional Jawa cenderung membelakangi gunung atau perbukitan serta menghadap ke laut, maka orientasi Dalem Kabupaten Jepara dapat didasarkan pada hal tersebut karena memiliki laut di bagian barat serta Gunung Muria di sebelah timur (belakang).

\subsection{Tata Massa}

Dalam skala tata massa bangunan, Dalem Kabupaten memiliki setidaknya empat bangunan utama yaitu pendopo, pringgitan, dalem, dan gandok sebagai komponen utama pembentuk tata ruang di dalam kompleks 
Kabupaten. Komponen lain yang menjadi pendukung dalam kompleks Dalem Kabupaten adalah keberadaan sumur yang dekat dengan posisi gandok. Keberadaan gandok yang dekat dengan sumur dimungkinkan karena fungsi gandok yang merupakan tempat tinggal abdi sehingga bersinggungan dengan kegiatan yang membutuhkan sumber air untuk kebutuhan sehari-hari. Selain itu adapula regol dengan langgam semar tinandu yang hanya dijumpai pada Dalem Kabupaten Brebes dan Rembang.

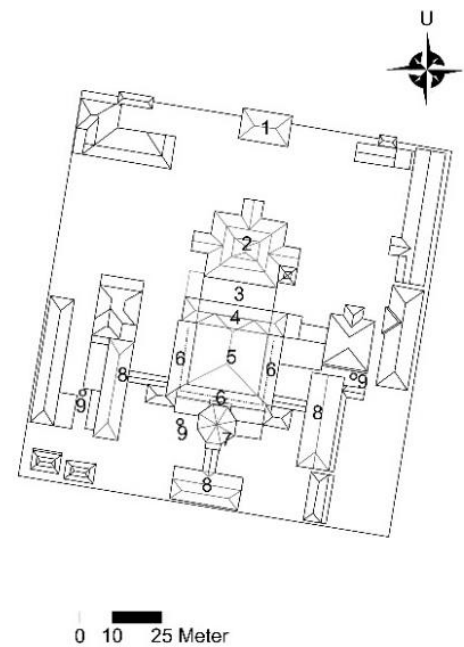

(a)

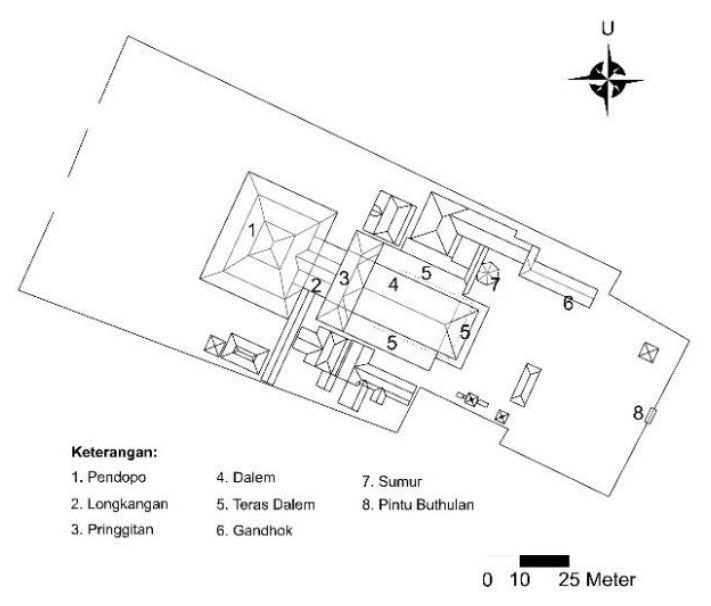

(c)

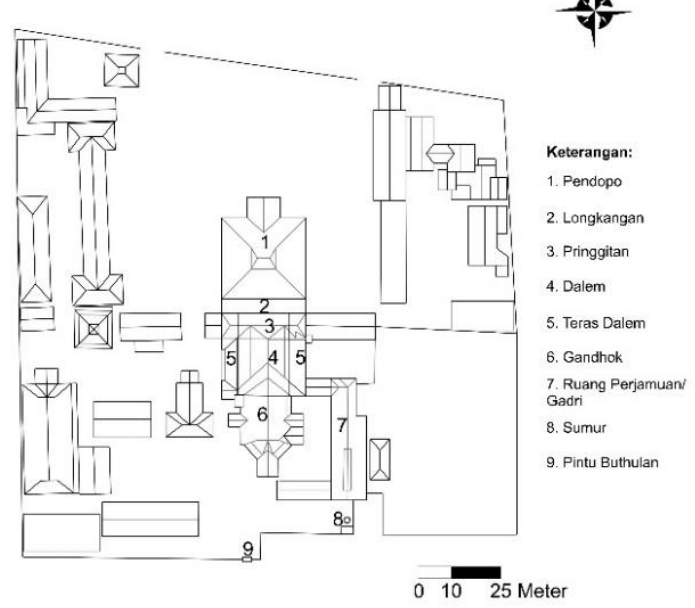

(b)

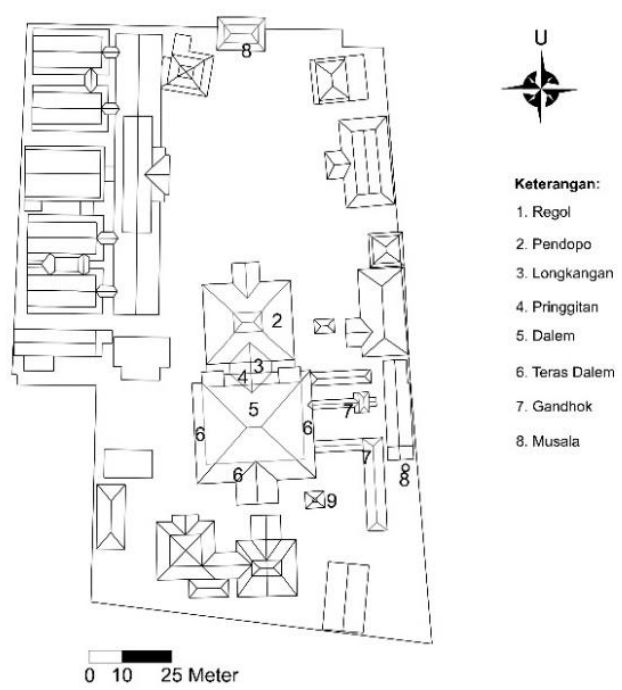

(d)

Gambar. 8

Tata Massa Dalem Kabupaten: (a) Brebes; (b) Pekalongan; (c) Jepara; dan (d)

Rembang

PAWON: Jurnal Arsitektur, Nomor 02 Volume V, Juli-Desember Tahun 2021, ISSN 2597-7636 
Skema tata massa bangunan menunjukkan Dalem Kabupaten memiliki plataran baik di depan dan belakang cukup luas. Dalam perkembangannya area tersebut kemudian dimanfaatkan untuk didirikan bangunan penunjang kantor kabupaten. Fungsi pada kompleks bangunan sangat berpengaruh terhadap keberadaan bangunan di sekelilingnya, misalnya saja pada Dalem Kabupaten di Pekalongan dan Rembang yang bangunan perkantorannya cukup massif karena sejak lama difungsikan sebagai area perkantoran, meskipun di Pekalongan saat ini sudah tidak digunakan lagi. Berbeda dengan bangunan yang ada di kompleks Dalem Kabupaten Jepara dan Brebes yang cenderung tidak banyak bangunan penunjang perkantoran karena berfungsi sebagai rumah dinas bupati. Bangunan utama Dalem Kabupaten berada pada posisi sentral di dalam kompleks, bentuk konsentris yang melekat dalam konsep bangunan tradisional Jawa. Massa bangunan utama yang berada di tengah ini kemudian dikelilingi oleh halaman baik depan, samping atau belakang dan disertai gandok.
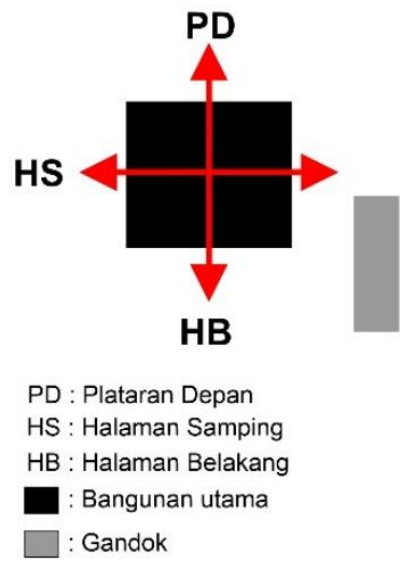

(a)

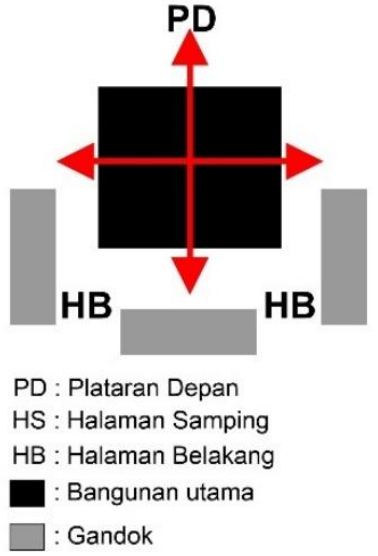

(b)

Gambar. 9

Posisi halaman pada Dalem Kabupaten (a) Pekalongan, Jepara, dan Rembang; (b) Brebes terhadap komponen bangunan utama di dalam Dalem Kabupaten

\subsection{Susunan Ruang}

Bangunan Dalem Kabupaten Pesisir Utara Jawa memiliki layout yang hampir mirip satu sama lain. Hal ini selain dapat dilihat susunan tata massa bangunannya juga melalui denah ruangan. Pada denah ruangan tersebut dapat dijumpai apa yang disebut oleh Sukesi (1985) sebagai jerambah atau ruang keluarga yang terletak di bagian tengah dan diapit oleh kamar di kanan dan kirinya. Namun demikian keberadaan jerambah bukan merupakan bentuk umum pada Dalem Kabupaten karena pada Dalem Kabupaten Pekalongan bagian ruangan jerambah ini digantikan dengan koridor. Besar kemungkinan pada waktu itu fungsi ruang servis yang cukup besar di bagian belakang (gambar 8.b) dirangkap pula sebagai jerambah. Berbeda dengan Dalem 
Kabupaten Brebes di mana terdapat jerambah dan ruang servis yang berada di bagian belakang serambi.

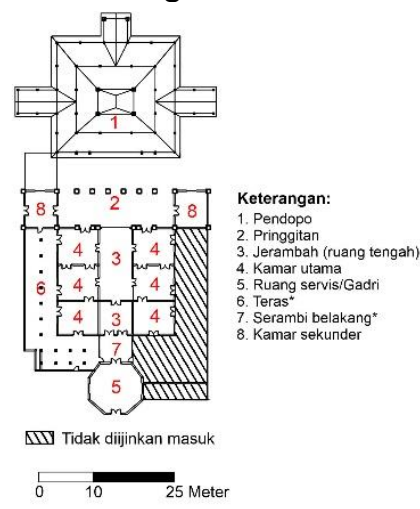

(a)

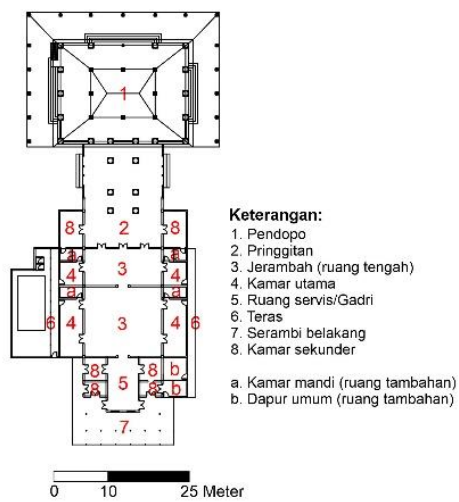

(c)

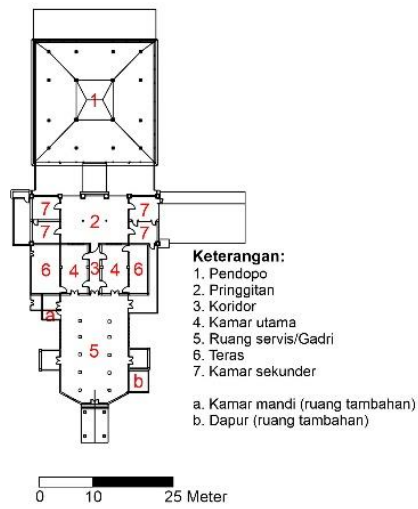

(b)

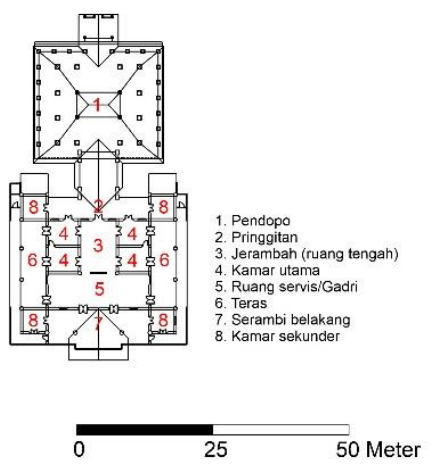

(d)

Gambar. 10

Denah Dalem Kabupaten: (a) Brebes; (b) Pekalongan; (c) Jepara; dan (d) Rembang

Dalem Kabupaten memiliki jumlah kamar utama yang beragam, pun demikian dengan jumlah kamar sekunder (secondary bedroom) yang biasa digunakan sebagai kamar anak maupun kamar tamu. Posisi kamar tamu dalam bangunan biasanya berada pada kamar sekunder yang berada di sisi kanan kiri pringgitan sedangkan pada kamar anak terdapat di dalam bangunan Dalem, termasuk juga pada kamar pingit RA Kartini yang berada di sisi kiri ruang servis (gambar 10). Ciri khas lain yang dimiliki Dalem Kabupaten adalah teras di sisi kanan kiri bangunan. Keberadaan teras ini dihubungkan dengan pintu-pintu pada kamar utama. Sementara itu pada Dalem Kabupaten selain Pekalongan, terdapat ruang terbuka yang biasa disebut serambi atau pendopo belakang. Ruangan ini masih tampak jelas ditunjukkan oleh Dalem 
Kabupaten Jepara sementara di Brebes dan Rembang sudah tidak lagi merupakan ruangan terbuka.

Dalem Kabupaten memiliki perbedaan utama yang signifikan jika dibandingkan dengan susunan ruang bangunan tradisional Jawa. Pada rumah tradisional Jawa, bagian sentral atau tengah ruangan menjadi bagian sakral di dalam Dalem di mana terdapat sentong tengah. Senthong tengah merupakan ruangan yang difungsikan sebagai tempat penghormatan pada Dewi Sri yang merupakan dewi kesuburan (Susanti dan Sunarimahingsih, 2020: 14; Idham, 2018). Sementara pada Dalem Kabupaten pesisir bagian ini digantikan oleh koridor atau jerambah. Dalam tulisan Idham (2018: 328-329), dinyatakan bahwa bangunan tradisional di Jawa bagian pedalaman sangat terikat dengan unsur budaya abangan sehingga ruang sakral di dalam rumah terus dipertahankan. Sementara itu, pada rumah tradisional Jawa di bagian pesisir (mancanegara) erat kaitannya dengan budaya santri yang secara perlahan menggeser tradisi. Keberadaan senthong di rumah pedalaman dimungkinkan juga terkait adanya budaya agraris karena terkait dengan penghormatan terhadap dewi kesuburan sementara di kota pesisir, sebagaimana lebih dikenal sebagai kota dagang (bukan agraris) hal semacam penghormatan kepada dewi kesuburan tersebut tidak dibutuhkan.

\section{KESIMPULAN}

Dalem Kabupaten di pesisir utara Jawa pada dasarnya merupakan bangunan dengan karakter spasial bangunan tradisional Jawa. Karakter ini menunjukkan adanya keragaman dan keseragaman pada masing-masing bangunan. Hal ini ditunjukkan dari orientasi bangunan yang dominan mengarah ke utara. Namun demikian orientasi ini juga diikuti oleh keberadaan posisi sungai, laut, dan gunung yang menjadi dasar orientasi keberadaan pusat kota. Alun-alun beserta masjid merupakan komponen utama yang turut ada di setiap pusat kota pesisir.

Dalam skala tata massa bangunan, Dalem Kabupaten memiliki empat komponen utama yang terdiri dari pendopo, pringgitan, dalem, dan gandok. Keempat komponen ini didukung dengan komponen tata massa lain seperti adanya regol, pintu buthulan, plataran depan, halaman samping, halaman belakang, dan sumur yang terletak di dekat gandhok. Keberadaan Dalem dalam skala tata massa bangunan ini menjadi pusat dari keseluruhan tata massa bangunan yang ada di dalam kompleks bangunan.

Sementara itu, susunan ruang yang terdapat di Dalem Kabupaten juga menunjukkan adanya kesamaan dengan ditunjukkan dari adanya teras-teras di sisi kanan-kiri bangunan. Ruangan bagian tengah atau yang disebut sebagai jerambah di Dalem Kabupaten merupakan pola dominan yang hanya tidak dimiliki oleh Dalem Kabupaten Pekalongan. Bagian ruang tengah ini

PAWON: Jurnal Arsitektur, Nomor 02 Volume V, Juli-Desember Tahun 2021, ISSN 2597-7636 
merupakan pembeda antara Dalem Kabupaten di pesisir utara Jawa dengan bangunan tradisional Jawa pada umumnya adalah keberadaan senthong tengah. Meskipun dalam skala tata ruang pusat kota bangunan ini masih menunjukkan karakter pusat kota tradisional Jawa namun dalam skala susunan ruang di dalam bangunan, Dalem Kabupaten tidak mengadopsi pola ruang yang ada pada bangunan tradisional Jawa.

\section{DAFTAR PUSTAKA}

Anonim. (2017). Sejarah Pemerintahan Daerah Istimewa Yogyakarta. Yogyakarta: Pemerintah Daerah Istimewa Yogyakarta.

Basundoro, Purnawan. (2020). Pengantar Sejarah Kota (Cetakan ke-3). Yogyakarta: Penerbit Ombak.

Damayanti, Rully dan Handinoto. (2005). Kawasan "Pusat Kota" Dalam Perkembangan Sejarah Perkotaan Jawa. Dimensi Teknik Arsitektur, Vol. 33, No.1, Juli 2005, Hal: 34-42.

Ds, Slamet. (1985). Arsitektur Tradisional Daerah Jawa Tengah. Departemen Pendidikan dan Kebudayaan, Direktorat Jendral Kebudayaan, Direktorat Sejarah dan Nilai Tradisional, Semarang.

Geertz, Clifford. (1981). Abangan, Santri, Priyayi Dalam Masyarakat Jawa. Jakarta: Pustaka Jaya.

Handinoto, (2010). Arsitektur dan Kota-Kota di Jawa Pada Masa Kolonial. Yogyakarta: Graha IImu.

Handinoto. (2015). Perkembangan Kota di Jawa Abad XVIII Sampai Pertengahan Abad XX Dipandang dari Sudut Bentuk dan Struktur Kotanya. Yogyakarta: Penerbit Ombak.

Hastati, Fauza. (2003). Karakteristik Arsitektural Bangunan Indis Pada Perumahan Pegawai Perusahaan Jawatan Kereta Api Pengok Blok A dan Blok $B$ di Yogyakarta. (Thesis, Program Pascasarjana, Universitas Gadjah Mada Yogyakarta).

Hidayatun, Maria I. (1999). Pendopo dalam era modernisasi : Bentuk, Fungsi dan Makna Pendopo pada Arsitektur Tradisional Jawa dalam Perubahan Kebudayaan. Dimensi Teknik Arsitektur Vol. 27, No. 1, Juli 1999, hal: $37-47$.

Idham, Noor Cholis. (2018). Javanese vernacular architecture and environmental synchronization based on the regional diversity of Joglo and Limasan. Frontier Architectural Research 7, 2018, hal: 317-333.

Ikaputra. (1995). A Study on the Contemporary Utilization of the Javanese Urban Heritage and its Effect on Historicity: an Attempt to Introduce the Contextual Adaptability into the Preservation of Historic City Environment of Yogyakarta. (Disertasi, Osaka University, Jepang). 
Lombard, Denys. (2018). Nusa Jawa Silang Budaya: 3. Warisan Kerajaan Konsentris (Cetakan ke-5). Jakarta: Gramedia Pustaka Utama.

Musman, Asti. (2017). Filosofi Rumah Jawa: Mengungkap Makna Rumah Orang Jawa. Bantul: Pustaka Jawi.

Oliveira, Vitor. (2016). Urban Morphology: An Introduction to the Study of Physical Form of Cities. Switszerland: Springer.

Santoso, Jo. (2008). Arsitektur-Kota Jawa: Kosmos, Kultur dan Kuasa. Jakarta: Centropolis - Magister Teknik Perencanaan Unoversitas Tarumanagara.

Sukesi. (1985). Bupati Pesisiran (Akhir Abad 19 Sampai Permulaan Abad 20). (Proyek Penelitian dan Pengkajian Kebudayaan Nusantara (Javanologi)). Direktorat Jenderal Kebudayaan. Yogyakarta.

Susanti, B Tyas dan Sunarimahingsih, Y.T. (2020). Rumah Tinggal "Tradisional" Pantura dikaji dari Aspek Tektonika dan Stilistika, Studi Kasus: Rumah Tradisional di Demak. (Laporan Penelitian, Fakultas Arsitektur dan Desain UNIKA Soegijapranata Semarang).

UNESCO. (2013). Nafas Baru Kota Sejarah: Penjelasan Tentang Pendekatan Lanskap Kota Bersejarah. Diterbitkan oleh UNESCO (2013). 